\title{
PENGARUHI PELAYANAN TERHADAP TINGKAT KEPUASAN PASIEN DI KLINIK SITI HAJAR MEDAN
}

\author{
Ester Hervina Sihombing, Didit Aji Wahyudi \\ Politeknik Unggul LP3M Medan \\ Jl.Iskandar Muda No.3 EF Medan-Sumatera Utara \\ www.politeknikunggul.ac.id, info@politeknikunggul.ac.id, \\ esterhervinasihombing@gmail.com
}

\begin{abstract}
Abstrak
Penelitian ini bertujuan untuk mengetahui apakah pelayanan berpengaruh terhadap kepuasan pasien pada Klinik Siti Hajar Medan. Hasil dari Penelitian ini menunjukkan bahwa Pelayanan sangat erat kaitannya dengan kepuasan pasien di klinik Siti hajar Medan ini terlihat dari hasil uji yang dilakukan. Populasi yang dipakai dalam penelitian ini adalah pasien pada Klinik Siti Hajar Medan dengan sampel yang digunakan sebanyak 65 orang responden yang, sedangkan teknis analisis data menggunakan analisis regresi linier sederhana, uji statistik (uji t dan koefisien determinasi). Dari hasil uji regresi linier sederhana nilai Signifikansi untuk variabel pelayanan $(0,00)$ lebih kecil dibandingkan dengan dari alpha $5 \%$ $(0,05)$ atau $t$ hitung $=8,806(n-2=30-2=28)>t$ table 1.70113 . Berdasarkan hasil analisis regresi linier sederhana, uji t dan uji determinasi maka dapat disimpulkan bahwa variabel pelayanan berpengaruh positif dan signifikan terhadap kepuasan pasien pada Klinik Siti Hajar Medan.
\end{abstract}

Kata Kunci : Pelayanan, Kepuasan Pasien.

Kata Kunci:

\section{PENDAHULUAN \\ 1.1. Latar Belakang}

Klinik adalah fasilitas
pelayanan kesehatan yang
menyelenggarakan pelayanan
kesehatan perorangan yang
menyediakan pelayanan medis
dasar dan spesialistik,
diselenggarakan oleh lebih dari
satu jenis tenaga kesehatan dan
dipimpin oleh seorang tenaga
medis. Kondisi yang demikian
membuat klinik membutuhkan
sistem manajemen dan pelayanan
yang baik untuk bisa berkembang

menjadi institusi yang memiliki daya saing dan kepekaan terhadap kebutuhan pasien sebagai konsumen terbesar.

Buruknya manajemen dan pelayanan jasa kesehatan yang diberikan klinik kepada pasien sudah sejak lama disadari mengakibatkan banyak kerugian baik bagi klinik bagi pasien. Survey membuktikan bahwa tidak setiap konsumen yang kecewa dengan pelayanan perusahaan dengan senang hati menyampaikan keluhannya. Artinya, meski pasien tidak 
menyampaikan keluhannya bukan berarti secara otomatis dianggap puas dengan pelayanan di klinik kenyataan bahwa konsumen yang tidak puas justru secara diamdiam beralih ke jasa pesaing . Itu artinya, diamnya pasien merupakan sinyal buruk. Karena yang menyampaikan keluhan biasanya adalah mereka yang benar-benar setia atau membutuhkan jasa rumah sakit.

Terkadang ada beberapa konsumen yang kecewa tidak hanya meninggalkan klinik, tetapi juga menceritakan keburukan pelayanan yang diterima pada orang lain. Hal ini akan berakibat fatal kepada pasien yang akan datang untuk berobat.

Menurut penelitian, mereka yang kecewa akan bercerita paling sedikit kepada 15 orang lainnya (Lupiyoadi \& Hamdani, 2006:47). Dengan asumsi 100 pasien yang kecewa, dalam satu bulan sinyal buruk itu akan menyebar ke 37.500 orang lainnya. Hal ini akan membuat citra buruk melekat dalam jasa pelayanan klinik. Berdasarkan hal tersebut, maka sangat diperlukan adanya upaya peningkatan kesadaran akan pentingnya membangun sistem manajemen pelayanan dan kualitas pelayanan klinik yang berfokus pada kepuasan pasien.

Survei kepuasan pasien menjadi penting dan perlu dilakukan bersamaan dengan pengukuran dimensi mutu layanan kesehatan yang lain. Keinginan pasien atau masyarakat dapat diketahui melalui survei kepuasan pasien. Pengalaman membuktikan bahwa transpormasi ekonomi pasti akan mengubah keinginan dan kebutuhan masyarakat terhadap layanan kesehatan. Oleh sebab itu pengukuran kepuasan pasien perlu dilakukan secara berkala dan akurat.

Jika belum sesuai dengan harapan pasien, maka hal tersebut akan menjadi suatu masukan bagi organisasi layanan kesehatan agar berupaya memenuhinya. Jika kinerja layanan kesehatan yang diperoleh pasien pada suatu fasilitas layanan kesehatan sesuai dengan harapannya, pasien pasti akan selalu datang berobat kepasilitas layanan kesehatan tersebut. Pasien akan selalu mencari layanan kesehatan di fasilitas yang kinerja layanan kesehatannya dapat memenuhi harapan atau tidak mengecewakan pasien.

Kepuasan pasien adalah perasaan senang dan kecewa pasien sebagai hasil perbandingan antara prestasi yang dirasakan dengan harapan. Pasien akan puas apabila layanan yang didapatkannya sekurangkurangnya sama atau melampaui harapan pasien. Sedangkan ketidakpuasan akan timbul apabila hasil tidak memenuhi harapan pasien.

Berbagai strategi yang dilakukan oleh klinik adalah untuk mempertahankan pasien dan juga untuk menambah pasien baru, memberikan pelayanan yang baik adalah salah satu bagian dari strategi yang dilakukan oleh Klinik Siti Hajar Medan. Pengetahuan yang diperoleh dari berbagai sumber informasi mengenai klinik juga akan mempengaruhi penilaian pasien terhadap Klinik Siti Hajar Medan. 
Bila pelayanan yang diberikan Klinik Siti Hajar Medan dapat menarik minat calon pasien baru, maka pasien akan merasa suka dan puas terhadap Klinik Siti Hajar Medan. Klinik Siti Hajar Medan memberikan pelayanan medis dasar dan spesialistik, di berikan oleh lebih dari satu jenis tenaga kesehatan dan dipimpin oleh seorang tenaga medis. Dari latar belakang masalah tersebut maka penulis mengangkat masalah tersebut dalam tugas akhir dengan judul "PENGARUH PELAYANAN TERHADAP KEPUASAN PASIEN DI KLINIK SITI HAJAR MEDAN"

\subsection{Perumusan Masalah}

Berpedoman kepada latar belakang pemilihan judul diatas, pembahasan ini difokuskan pada hal-hal berikut :

1. Pelayanan apa saja yang diberikan kepada pasien di klinik Siti Hajar Medan

2. Pengaruh pelayanan terhadap kepuasan pasien di klinik Siti Hajar Medan.

\subsection{Tujuan Penelitian}

Tujuan yang diinginkan dalam penulisan ini yakni :

1. Menganalisis pelayanan apa saja yang diberikan kepada pasien di klinik Siti Hajar Medan.

2. Menganalisis pengaruh pelayanan terhadap kepuasan pasien di Klinik Siti Hajar Medan.

\subsection{Manfaat Penulisan}

Ada beberapa manfaat yang diambil dalam penelitian ini antara lain :

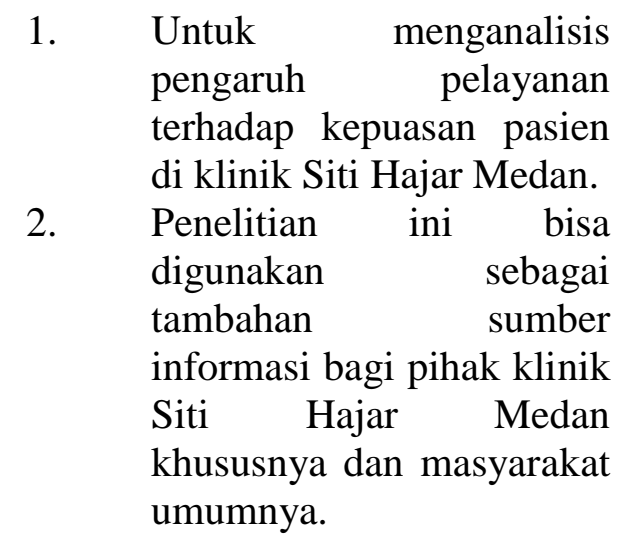

\section{METODE PENELITIAN}

2.1. Ruang Lingkup Penelitian

Ruang lingkup penelitian ini meliputi : Pengaruh pelayanan terhadap kepuasan pasien di Klinik Siti Hajar Medan.

\subsection{Jenis dan Sumber Data}

\subsubsection{Jenis Data}

Jenis data yang digunakan penulis pada penelitian ini adalah :

a. Data Kualitatif yaitu data dalam bentuk kata, kalimat ataupun gambar.

b. Data Kuantitatif yaitu data dalam bentuk angka atau data kuantitatif yang diangkakan.

\subsubsection{Sumber Data}

Sumber data berasal dari :

a. Data Primer, yaitu data yang diperoleh langsung dari objek yang diteliti mengenai data-data yang berhubungan langsung dengan peneliti.

b. Data sekunder, yaitu data yang diperoleh secara tidak langsung dengan mempelajari buku-buku, literature. 


\subsection{Teknik Pengumpulan Data}

Teknik pengumpulan data adalah cara mendapatkan informasi selengkaplengkapnya dari narasumber atau reponden. Teknik yang tepat akan mengefektifkan pengumpulan data, serta cara terbaik mendapatkan data yang akurat dan maksimal. Untuk melengkapi data yang diperlukan maka Penulis menggunakan alat/instrumen penelitian yaitu:

1. Observasi (Pengamatan) Observasi merupakan pengamatan yang meliputi pemusatan perhatian terhadap suatu objek yang dilakukan dengan cara melihat secara langsung kepada kegiatan dari objek kantor tersebut dengan cara memantau aktifitasaktifitas yang dilakukan klinik Siti Hajar Medan.

2. Interview (wawancara)

Peneliti langsung mengadakan tanya jawab dengan pihak-pihak yang berkompeten langsung dengan penelitian untuk mendapatkan data-data yang penulis perlukan.

3. Studi Dokumen

Yaitu penelitian yang dilakukan dengan mengunakan dokumen dan bahan literatur lainnya sesuai dengan pembahasan penelitian penulis sebagai bahan rujukan dan pertimbangan.

\subsection{Teknik Analisis Data}

Metode analisa data yang dipergunakan dalam penulisan ini adalah : Metode deskriptif, yaitu suatu metode dimana data yang telah diproses, disusun, dikelompokkan, dianalisis, kemudian diinterpretasikan sehingga diperoleh gambaran tentang masalah yang dihadapi.

\section{HASIL PEMBAHASAN}

\subsection{Karakteristik Responden Berdasarkan Jenis Kelamin}

Gambaran umum responden yang ada dalam penelitian ini adalah pasien Klinik Siti Hajar Medan berdasarkan jenis kelamin, dapat dilihat pada Tabel 3.1 berikut :

Tabel 3.1

Karakteristik Responden Berdasarkan Jenis Kelamin

\begin{tabular}{|c|c|c|}
\hline $\begin{array}{c}\text { Jenis } \\
\text { Kelamin }\end{array}$ & $\begin{array}{c}\text { Jumlah } \\
\text { (Orang) }\end{array}$ & $(\%)$ \\
\hline Pria & 30 & 46 \\
Wanita & 35 & 54 \\
\hline Total & 65 & 100 \\
\hline Sumber: Diolah Peneliti
\end{tabular}
(2015)

Hasil penelitian berdasarkan jenis kelamin pada Tabel 3.1. menunjukkan bahwa responden bedasarkan jenis kelamin pada Klinik Siti Hajar Medan yang paling banyak adalah pasien yang berjenis kelamin wanita yang berjumlah 35 orang (54\%).

\subsection{Karakteristik Responden Berdasarkan Tingkat Pendidikan}


responden yang ada dalam penelitian ini adalah pasien Klinik Siti Hajar Medan berdasarkan tingkat pendidikan, dapat dilihat pada Tabel 3.2 berikut :

Tabel 3.2

Karakteristik Responden Berdasarkan Tingkat Pendidikan

\begin{tabular}{|c|c|c|}
\hline $\begin{array}{c}\text { Tingkat } \\
\text { Pendidikan }\end{array}$ & $\begin{array}{c}\text { Jumlah } \\
\text { (Orang) }\end{array}$ & $\mathbf{( \% )}$ \\
\hline SMP & 10 & 15,38 \\
\hline SMA/SMK & 25 & 38,48 \\
\hline DIPLOMA 3 & 15 & 23,07 \\
\hline S1 & 15 & 23,07 \\
\hline Jumlah & 65 & 100 \\
\hline
\end{tabular}

Sumber: Diolah Peneliti (2015)

Berdasarkan tabel di atas diketahui bahwa seluruh responden masih bersekolah yaitu sebanyak 25 pasien atau $38,48 \%$.

\subsection{Karakteristik Responden Berdasarkan Usia}

Gambaran umum responden yang ada dalam penelitian ini adalah pasien Klinik Siti Hajar Medan berdasarkan usia, dapat dilihat pada Tabel 3.3 berikut :

Tabel 3.3

\section{Karakteristik Responden Berdasarkan Usia}

\begin{tabular}{|c|c|c|}
\hline $\begin{array}{c}\text { Usia } \\
\text { (Tahun) }\end{array}$ & $\begin{array}{c}\text { Jumlah } \\
\text { (Orang) }\end{array}$ & $(\%)$ \\
\hline $15-20$ & 35 & 53,86 \\
\hline $20-30$ & 15 & 23,07 \\
\hline $30-40$ & 15 & 23,07 \\
\hline Total & 65 & 100 \\
\hline
\end{tabular}

Hasil penelitian berdasarkan tingkat usia pada Tabel 3.3. menunjukkan bahwa dari jumlah responden yang diteliti sebanyak 65 orang usia pasien Klinik SitiHajar Medan adalah usia paling banyak adalah $15-20$ tahun sebanyak 35 orang $(53,86 \%)$.

\subsection{HasilPenelitian \\ 3.4.1 Uji Validitas}

a. Variabel Pelayanan $(X)$

Uji validitas digunakan untuk mengukur sah atau valid tidaknya suatu kuesioner. "Suatu kuesioner dikatakan valid jika pertanyaan pada kuesioner mampu untuk mengungkapkan sesuatu yang akan diukur oleh kuesioner tersebut" (Imam Ghozali, 2006). Untuk mengukur validitas dapat dilakukan dengan melakukan korelasi antar skor butir pertanyaan dengan total skor konstruk atau variabel.

Tabel 3.4

Item-Total Statistics

\begin{tabular}{|l|r|r|r|r|}
\hline & $\begin{array}{r}\text { Scale Mean if } \\
\text { Item Deleted }\end{array}$ & $\begin{array}{r}\text { Scale Variance } \\
\text { if Item Deleted }\end{array}$ & $\begin{array}{r}\text { Corrected Item- } \\
\text { Total } \\
\text { Correlation }\end{array}$ & $\begin{array}{c}\text { Cronbach's } \\
\text { Alpha if Item } \\
\text { Deleted }\end{array}$ \\
\hline pertanyaan 1 & 31,2923 & 6,273 &, 723 &, 827 \\
pertanyaan 2 & 31,3692 & 6,643 &, 523 &, 850 \\
pertanyaan 3 & 31,3385 & 7,040 &, 397 &, 864 \\
pertanyaan 4 & 31,2923 & 6,523 &, 611 &, 840 \\
pertanyaan 5 & 31,3538 & 6,326 &, 704 &, 829 \\
pertanyaan 6 & 31,3538 & 6,638 &, 566 &, 845 \\
pertanyaan 7 & 31,3077 & 6,404 &, 615 &, 839 \\
pertanyaan 8 & 31,2923 & 6,335 &, 694 &, 830 \\
\hline
\end{tabular}

Dari Tabel 3.4 di atas diketahui, diketahui nilai correlation pertanyaan untuk pelayanan seluruhnya sudah 
valid karena nilai validitas seluruhnya lebih besar dari 0,361 , dan bisa digunakan dalam perhitungan selanjutnya karena seluruhnya dinyatakan valid.

\section{b. Variabel Kepuasan} (Y)

Uji validitas digunakan untuk mengukur sah atau valid tidaknya suatu kuesioner. "Suatu kuesioner dikatakan valid jika pertanyaan pada kuesioner mampu untuk mengungkapkan sesuatu yang akan diukur oleh kuesioner tersebut" (Imam Ghozali, 2006). Untuk mengukur validitas dapat dilakukan dengan melakukan korelasi antar skor butir pertanyaan dengan total skor konstruk atau variabel.

Tabel 3.5

Item-Toal stastistic

\begin{tabular}{|c|c|c|c|c|}
\hline & $\begin{array}{l}\text { Scale Mean if } \\
\text { Item Deleted }\end{array}$ & \begin{tabular}{|l|} 
Scale Variance \\
if them Deleted
\end{tabular} & \begin{tabular}{|c|} 
Corrected ltem- \\
Total \\
Correlation
\end{tabular} & $\begin{array}{c}\text { Cronbach's } \\
\text { Alpha if Item } \\
\text { Deleted }\end{array}$ \\
\hline \begin{tabular}{|l|} 
pertanyaan 1 \\
\end{tabular} & 31,1231 & 6,985 & ,398 & .850 \\
\hline pertanyaan 2 & 31,1231 & 6,641 & ,541 & .834 \\
\hline pertanyaan 3 & 31,2308 & 5,837 & ,757 & 804 \\
\hline pertanyaan 4 & 31,2000 & 6,631 & ,509 & 838 \\
\hline pertanyaan 5 & 31,1538 & 6,413 & ,640 & .822 \\
\hline pertanyaan 6 & 31,2615 & 6,759 &, 516 & .836 \\
\hline pertanyaan 7 & 31,2000 & 6,288 & ,652 & 820 \\
\hline pertanyaan 8 & 31,1231 & 6,391 & ,649 & .821 \\
\hline
\end{tabular}

Sumber: Diolah Peneliti (2015)

Dari Tabel 3.5 di atas diketahui, diketahui nilai correlation pertanyaan untuk kepuasan pasien seluruhnya sudah valid karena nilai validitas seluruhnya lebih besar dari 0,361 , dan bisa digunakan dalam perhitungan selanjutnya karena seluruh nya dinyatakan valid.

\subsubsection{UjiReliabilitas}

Uji reliabilitas dapat dilakukan dengan menggunakan bantuan program SPSS, yang akan memberikan fasilitas untuk mengukur reliabilitas dengan uji statistik Cronbach Alpha ( $\alpha$ ). "Suatu konstruk atau variabel dikatakan reliabel jika memberikan nilai Cronbanch Alpha > 0,60". ( Ghozali,2006).

Tabel 3.6

Hasil Uji Reliabilitas

\begin{tabular}{|c|c|}
\hline Variabel & $\begin{array}{c}\text { Nilai Cronbach } \\
\text { Alpha }\end{array}$ \\
\hline Pelayanan & 0,858 \\
\hline Kepuasan & 0,847 \\
\hline
\end{tabular}

Sumber : Hasil Perhitungan SPSS

Berdasarkan tabel 3.6 di atas diketahui nilai Cronbach Alpha untuk seluruh variabel melebihi angka 0,60 sehingga variabel kepuasan dikatakan sudah handal (reliabel).

\subsection{AnalisisDeskriptif}

\subsubsection{Deskripsi Variabel Pelayanan $(\mathrm{X})$}

Hasil analisis deskripstif dari jawaban responden untuk variabel pelayanan yaitu sebagai berikut

Tabel 3.7

Tabulasi Pelayanan $(\mathrm{X})$

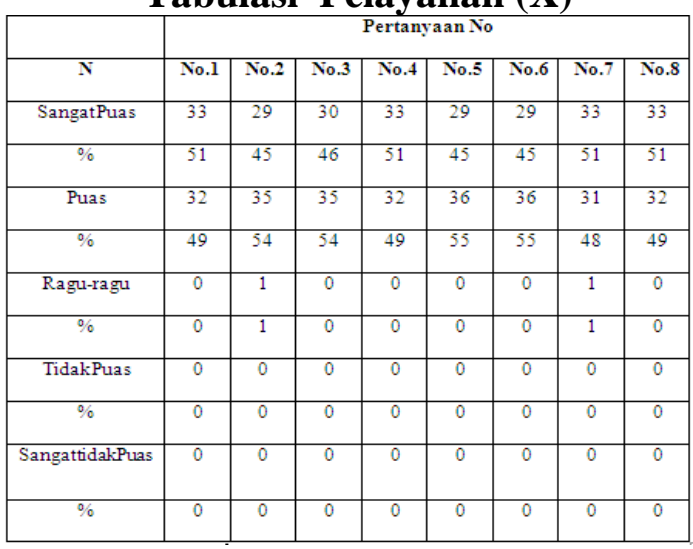

Sumber: Diolah Peneliti (2015) 
Berdasarkan tabel 3.7.

dapat diketahui hasil sebagai

berikut :

1. Pertanyaan nomor 1 (Kondisi gedung Klinik Siti Hajar Medan dalam keadaan baik) sebanyak 33 $(51 \%)$ responden memberikan jawaban sangat setuju dan 32 (49\%) memberikan jawaban setuju.

2. Pertanyaan nomor 2 (Peralatan kesehatan yang baik diberikan Klinik Siti Hajar Medan) sebanyak 29 $(45 \%)$ responden memberikan jawaban sangat setuju, 35 (54\%) responden memberikan jawaban setuju dan sebanyak $1 \quad(1 \%)$ responden memberikan jawaban Ragu - ragu.

3. Pertanyaan nomor 3 (Perawat memberikan pelayanan dengan tepat untuk anda) sebanyak 30 (46\%) responden memberikan jawaban sangat setuju dan 35 (54\%) memberikan jawaban setuju.

4. Pertanyaan nomor 4 (Dokter mendengarkan baik-baik ketika pelanggan meminta pelayanan) sebanyak $\quad 33 \quad(51 \%)$ responden memberikan jawaban sangat setuju dan 32 (49\%) memberikan jawaban setuju.

5. Pertanyaan nomor 5 (Dokter cepat merespon terhadap keluhan anda) sebanyak $29 \quad$ (45\%) responden memberikan jawaban sangat setuju dan $36 \quad(55 \%)$ memberikan jawaban setuju.

6. Pertanyaan nomor 6 (Dokter bersedia untuk membantu menyelesaikan keluhan anda) sebanyak $29 \quad(45 \%)$ responden memberikan jawaban sangat setuju dan $36(55 \%)$ memberikan jawaban setuju.

7. Pertanyaan nomor 7 (Dokter tahu bagaimana menyelesaikan keluhan anda) sebanyak33 (51\%) responden memberikan jawaban sangat setuju, 31 (48\%) memberikan jawaban setuju dan sebanyak 1 (1\%) responden menjawab Ragu - ragu.

8. Pertanyaan nomor 8 (Dokter memiliki perhatian yang baik kepada anda) sebanyak $33 \quad(51 \%)$ responden memberikan jawaban sangat setuju dan $32(49 \%)$ memberikan jawaban setuju.

\subsubsection{Deskripsi Variabel Kepuasan (Y) \\ Berikut hasil analisis deskriptif dari jawaban responden variabel kepuasan pelanggan.}


Tabel 3. 8

Tabulasi Kepuasan (Y)

\begin{tabular}{|c|c|c|c|c|c|c|c|c|}
\hline & \multicolumn{7}{|c|}{ Pertanyaan No } \\
\hline & $\begin{array}{c}N_{0} \\
1\end{array}$ & $N_{0.2}$ & $N_{0.3}$ & $N_{0.4}$ & $N_{0.5}$ & $N_{0.6}$ & $N_{0.7}$ & $N_{0.8}$ \\
& 1 & & & & & & \\
\hline SangatPuas & 33 & 33 & 29 & 29 & 31 & 24 & 29 & 33 \\
\hline$\%$ & 51 & 51 & 45 & 45 & 48 & 37 & 45 & 51 \\
\hline Puas & 32 & 32 & 33 & 35 & 34 & 41 & 35 & 32 \\
\hline$\%$ & 49 & 49 & 51 & 54 & 52 & 63 & 54 & 49 \\
\hline Ragu-ragu & 0 & 0 & 3 & 1 & 0 & 0 & 1 & 0 \\
\hline$\%$ & 0 & 0 & 4 & 1 & 0 & 0 & 1 & 0 \\
\hline TidalPuas & 0 & 0 & 0 & 0 & 0 & 0 & 0 & 0 \\
\hline$\%$ & 0 & 0 & 0 & 0 & 0 & 0 & 0 & 0 \\
\hline SangattidalPua & 0 & 0 & 0 & 0 & 0 & 0 & 0 & 0 \\
\hline 5 & & & & & & & & \\
\hline$\%$ & 0 & 0 & 0 & 0 & 0 & 0 & 0 & 0 \\
\hline
\end{tabular}

Sumber: Diolah Peneliti (2015)

Berdasarkan tabel 3.8 dapat diketahui hasil sebagai berikut :

1. Pertanyaan nomor 1(Pasien merasa nyaman jika berada di ruangan perusahaan)sebanyak $33 \quad(51 \%)$ responden memberikan jawaban sangat setuju dan $32 \quad$ (49\%) memberikan jawaban setuju.

2. Pertanyaan nomor 2(Pasien merasa senang dengan kemampuan yang dimiliki karyawan dalam memberikan pelayanan)sebanyak $33(51 \%)$ responden memberikan jawaban sangat setuju dan 32 (49\%) memberikan jawaban setuju.

3. Pertanyaan nomor 3(Karyawan perusahaan melayani dengan baik)sebanyak $29 \quad(45 \%)$ responden memberikan jawaban sangat setuju, 33 (51\%) memberikan jawaban setuju dan sebanyak 3 (4\%) responden menjawab Ragu ragu.
4. Pertanyaan nomor 4 (Pasien merasa puas dengan pelayanan karyawan)sebanyak $\quad 29$ (45\%) responden memberikan jawaban sangat setuju 35 (54\%) memberikan jawaban setuju dan sebanyak 1(1\%) responden menjawab Ragu - ragu.

5. Pertanyaan nomor 5 (Karyawan memiliki kemampuan yang baik dalam memberikan pelayanan) sebanyak 31 (48\%) responden memberikan jawaban sangat setuju dan 34 (52\%) memberikan jawaban setuju.

6. Pertanyaan nomor 6 (Pasien merasa senang setelah mendapatkan pelayanan karyawan) sebanyak $24 \quad(37 \%)$ responden memberikan jawaban sangat setuju dan $41 \quad(63 \%)$ memberikan jawaban setuju.

7. Pertanyaan nomor 7 (Pasien tersenyum setelah keluhannya dilayani karyawan)sebanyak $\quad 29$ (45\%) responden memberikan jawaban sangat setuju, 35 (54\%) memberikan jawaban setuju dan sebanyak 1 (1\%) responden menjawab Ragu - ragu.

8. Pertanyaan nomor 8 (Pasien merasa senang telah di beri perhatian kepada karyawan) sebanyak $33 \quad(51 \%)$ responden memberikan jawaban sangat setuju dan 
32 (49\%) memberikan jawaban setuju.

\subsection{AnalisisKuantitatif}

\subsubsection{AnalisisRegresi Linier Sederhana}

Untuk mempermudah pembacaan hasil dan interpretasi analisis regresi maka digunakan persamaan. Persamaan atau model tersebut berisi konstanta dan koefisien-koefisien regresi yang didapat dari hasil pengolahan data yang telah dilakukan sebelumnya. Persamaan regresi yang telah dirumuskan kemudian dengan bantuan program SPSS dilakukan pengolahan data sehingga didapat persamaan akhir sebagai berikut :

Tabel 3.9

Uji Regresi Linier Sederhana

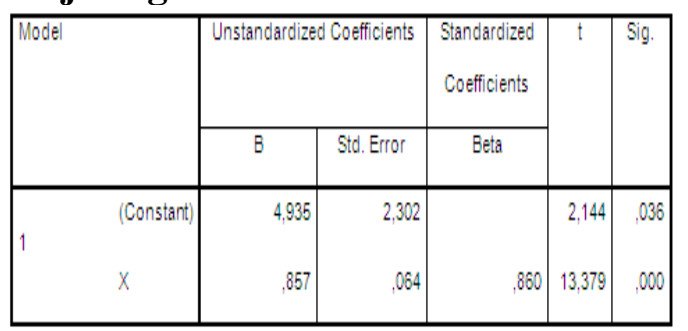

Berdasarkan Tabel 3.9 di atas, maka persamaan regresi linier sederhana dalam penelitian ini adalah :

$$
\mathrm{Y}=\mathbf{4 , 9 3 5}+\mathbf{0 , 8 5 7} \mathrm{X}
$$

Pada model regresi ini, nilai konstanta yang tercantum sebesar 4,935dapat diartikan jika variabel bebas dalam model diasumsikan sama dengan nol, secara rata-rata variabel diluar model tetap akan meningkatkan pelaayanan sebesar 4,935 satusatuan. Dengan kata lain jika pelayanan tidak ditingkatkan, maka kepuasan pasien masih sebesar 4,935 satuan.
Nilai besaran koefisien regresi $\beta_{1}$ sebesar $\mathbf{0 , 8 5 7}$ pada penelitian ini dapat diartikan bahwa variabel promosi berpengaruh positif dengan kepuasan pasien Klinik Siti Hajar Medan. Hal ini menunjukkan bahwa ketika pelayanan ditingkatkan sebesar satu satuan, maka kepuasan pasien di Klinik Siti Hajar Medan juga akan mengalami peningkatan sebesar $\mathbf{0 , 8 5 7}$ satuan.

\subsubsection{Uji Parsial (Uji t)}

Hasil pengujian

hipotesis pertama secara parsial dapat dilihat pada tabel 3.10 berikut :

Tabel 3.10

Uji Hasil Uji T

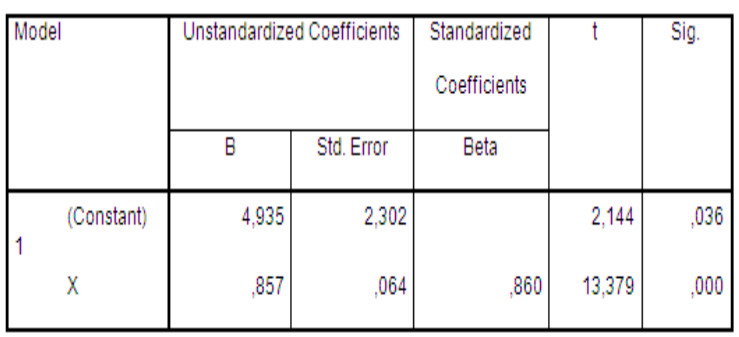

Dari Tabel 3.10 di atas diperoleh hasil sebagai berikut :

Nilai Signifikansinya untuk variabel promosi $(0,00)$ lebih kecil dibandingkan dengan dari alpha $5 \%(0,05)$ atau $\mathrm{t}$ hitung $=13,379(\mathrm{n}-\mathrm{k}=65-2=63)>$ t table 1,669. Berdasarkan hasil yang diperoleh maka menolak Ho dan menerima.Ha. maka variabel pelayanan berpengaruh positif dan signifikan terhadap kepuasan pasien di Klinik Siti Hajar Medan. 


\subsubsection{Uji Determinasi $\left(\mathbf{R}^{2}\right)$}

Nilai koefisien determinasi $\left(\mathrm{R}^{2}\right)$ dipergunakan untuk mengukur besarnya hubungan variabel bebas yang terdiri dari tingkat kepuasan pasien di Klinik Siti Hajar Medan. Hasil Uji determinasi dapat dilihat pada Tabel 3.11. Berikut ini:

Tabel. 3.11

Hasil Uji Determinasi $\left(\mathbf{R}^{2}\right)$ Model Summary

\begin{tabular}{|l|r|r|r|r|}
\hline Model & $\mathrm{R}$ & R Square & \multicolumn{1}{|c|}{$\begin{array}{c}\text { Adjusted R } \\
\text { Square }\end{array}$} & $\begin{array}{c}\text { Std. Error of the } \\
\text { Estimate }\end{array}$ \\
\hline 1 &, $860^{3}$ & $\mathbf{1 7 4 0}$ &, 736 & 1,48149 \\
\hline
\end{tabular}

Berdasarkan Tabel 3.11

diperoleh nilai regresi korelasi sebesar 0,860, artinya secara bersama-sama pelayanan mampu menjelaskan kepuasankonsumen pada taraf yang erat dan positif. Kemudian koefisien determinasi $\left(\mathrm{R}^{2}\right)$ sebesar $0.740 \quad(74,0 \%)$. Sehingga dapat dikatakan bahwa $74 \%$ variasi variabel bebas yaitu pelayananpada model summary dapat menjelaskankepuasanpasien sedangkan sisanya sebesar $26 \%$ dipengaruhi oleh variabel lain di luar model summary.

\subsection{Pembahasan}

Berdasarkan hasil analisa data diketahui bahwa nilai Signifikansi untukvariabel pelayanan $(0,00)$ lebih kecil dibandingkan dengan dari alpha $5 \%(0,05)$ atau $t$ hitung $=13,379$ $(\mathrm{n}-\mathrm{k}=65-2=63)>\mathrm{t}$ table 1,669 . Berdasarkan hasil yang diperoleh maka penelitian menolak Ho dan menerima.Ha maka variabel kepuasan berpengaruh positif dan signifikan terhadap tingkat kepuasanpasien di Klinik Siti Hajar Medan.

\section{KESIMPULAN DAN SARAN}

4.1

1. Keefektifan pencairan tunggakan pajak adalah tingkat keberhasilan atau ketepatan sasaran yang dicapai dari usaha melunasi utang pajak oleh wajib pajak/penanggung pajak dengan tujuan yang berhubungan dengan penyelenggaraan pemerintahan.

2. Kantor Pelayanan Pajak Pratama Medan Kota ialah salah satu unsur pelaksana kegiatan operasional pemberian pelayanan di lingkungan Direktorat Jenderal Pajak Kanwil Sumut I dan bertugas menghimpun penerimaan negara dari sektor pajak.

3. Salah satu tugas dari KPP Pratama Medan Kota ialah melaksanakan penagihan dengan melakukan pencairan tunggakan pajak untuk meningkatkan penerimaan pajak.

4. Tingkat keefektifan pencairan tunggakan pajak dari tahun 2010 sampai dengan tahun 2014 masih kurang efektif, dimana perbandingan realisasi tunggakan pajak dan total tunggakan pajak setiap tahun pada KPP Pratama Medan Kota adalah berbanding tegak lurus, yang realisasinya mengalami peningkatan tetapi total tunggakan pajaknya juga meningkat selama lima tahun terakhir, hal ini dikarenakan adanya upaya penggalian 
potensi penerimaan pajak (extraeffort).

5. Tingkat keefektifan penerimaan pajak dari tahun 2010 sampai dengan tahun 2014 efektif, dimana untuk tahun 2010 sampai 2012 realisasi penerimaan pajak telah mencapai target/rencana penerimaan pajak, dan untuk tahun 2013 sampai 2014 memperoleh jumlah realisasi yang masih mendukung dari target/rencana penerimaan pajak.

6. Hambatan-hambatan yang ditemukan dalam pelaksanaan penagihan pencairan tunggakan pajak dapat dilihat dari minimnya pengetahuan wajib pajak tentang peraturan perpajakan beserta rendahnya kesadaran wajib pajak akan kewajiban perpajakannya terbukti dengan penambahan tunggakan yang semakin meningkat, yang selanjutnya adalah dilihat dari kinerja fiskus dengan adanya penambahan tunggakan yang tidak diimbangi dengan pencairan tunggakannya.

\subsection{Saran}

Bagi pihak Klinik Siti Hajar Medan Untuk mewujudkan pelayanan kesehatan yang prima maka pihak Klinik Siti Hajar Medan disarankan untuk memperbaiki dan meningkatkan lagi kualitas pelayanan kesehatan berdasarkan prioritas utama, yaitu dengan cara:

1. Melengkapi fasilitas dan perlengkapan di ruangan dengan cara memperbaiki alatalat yang rusak di ruangan dan menambahkan inventoris ruangan berdasarkan prioritas pasien.

2. Membatasi jumlah pengunjung yang boleh berada di ruangan pasien dan meningkatkan pengawasan terhadap jam berobat pasien.

3. Melakukan survey kemampuan masyarakat sebelum menetapkan tarif dan biaya pelayanan di rumah sakit.

\section{DAFTAR PUSTAKA}

Budiastuti, 2002, Faktor-faktor dalam Meningkatkan Kepuasan Pasien di Rumah Sakit, http/www/klinis_wordpress//Kepu asan Pasien terhadap Pelayanan Keperawatan, diunduh pada tanggal 7 September 2015.

Depkes RI, 2012, tentang Pelayanan Kesehatan.

Fandi, Tjiptono \& Gregorius Chandra, 2005, Service, Quality, Satisfaction, Andi Offset, Yogyakarta.

Ghozali, Iman, 2006, Statistik Nonparametik, Badan Penerbit UNDIP, Semarang

Indarjati A， 2001, Kepuasan Konsumen, Pranata No.I Tahun IV.

Kartajaya, Hermawan, 2009, Service Operation, Airlangga, Jakarta.

Kriyantono, Rachmat, 2008, Teknik Praktis Riset Komunikasi, Kencana Prenada Media Group, Jakarta. 
Kotler dan Keller, 2006, Manajemen Pemasaran, Edisi XI, Jilid I, PT. Indeks, Jakarta.

Rahmayanty, Nina, 2012, Manajemen Pelayanan Prima, Graha Ilmu, Yogyakarta. 